\title{
LANGUAGE AND COMMUNICATION MEDIA
}

DOI https://doi.org/10.30525/978-9934-588-90-7-68

\section{ФУНКЦЙНІ ВИЯВИ ТЕРМІНА ЯК ОДИНИЦІ ЕКОНОМІЧНОГО ДИСКУРСУ}

\author{
Архипенко Л. М. \\ кандидат філологічних наук, доцент, \\ дочент кафедри українознавства і мовної підготовки \\ іноземних громадян \\ Харківський наиіональний економічний університет \\ імені Семена Кузнеия \\ м. Харків, Україна
}

Сьогодні спостерігаємо фундаментальні зміни у всіх сферах життя нашої держави, які, безумовно, не могли не позначитися на мовленні громадян. Докорінна перебудова державної системи, усіх сторін економічного життя спричинила рух відповідних процесів у мові: як у словниковому складі, так i в його термінологічній складовій. «Термінологічний вибух», який ми сьогодні спостерігаємо, повною мірою стосується економічної галузі знань, призводить до постійного розширення іiі понятійного апарату. Якісні історичні зміни характеру наукового пізнання супроводжуються постійним кількісним зростанням обсягу всієї спеціальної лексики. Результатом розвитку науковотехнічної революції $є$ безпрецедентне зростання кількості неологізмів у мові, які в основному позначають спеціальні термінологічні поняття. За спостереженнями дослідників терміни складають переважну більшість.

Останнім часом певні терміносистеми поповнилися значною кількістю нових україномовних термінів, створених у результаті компенсації понятійних лакун. I перш за все це стосується економічних термінів, адже в кінці XX - на початку XXI ст. економічні відносини стали «провідниками» нових термінів із європейських мов. Саме ця ситуація спричинила особливий інтерес до економічної терміносистеми як, безсумнівно, найбільш рухомої й значущої частини спеціальної лексики, до iï ретельного й усебічного аналізу. Дослідження мови як знакового й структурного об'єкта вимагає системного підходу.

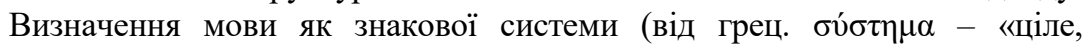
складене 3 частин; по'єднання») - множинність елементів, що 
перебувають у певних відносинах і зв'язках й утворюють певну цілісність, єдність належить Ф. де Соссюру й підготовлене тривалою традицією, у тому числі дискусіями античних граматистів про співвідношення аномалії й аналогії в мові, працями В. фон Гумбольдта, А. Шлейхера, І.А. Бодуена де Куртене.

В. фон Гумбольдт вважав, що «мова має супроводжувати думки. Думка, не відстаючи від мови, повинна слідувати від одного ії елемента до іншого й знаходити в мові позначення для всього, що робить іiї зв'язаною... Щоб відповідати мисленню, мова, наскільки це можливо, своєю будовою має відповідати внутрішній організації мислення» [3, с. 345]. У цьому сенсі термінологічна система, зокрема й галузі економіки, є зручним об'єктом для розгляду системних внутрішньомовних відносин. Термінологами встановлено, що сам процес деривації, створення терміна $\epsilon$ більш складним порівняно зі створенням загальновживаного слова. Зважаючи на це В.П. Даниленко зазначає: «якщо для останнього достатнім можна вважати використання одного $з$ наявних способів словотворення, то для терміна необхідне ще словесне розкриття змісту термінологічної номінації, тобто дефініції поняття. I це входить до словотворчого акту новоствореного терміна, оскільки без дефініції, без визначення меж змісту поняття, без виділення тих ознак, які вирізняли б це поняття поміж інших, термін не можна вважати повноцінним» [4, с. 94].

У сучасному термінознавстві розглядають різні принципи, аспекти та способи термінологічної номінації. Особлива увага приділяється препозитивному та соціально-комунікативному характеру терміна. У термінологічній номінації можна виділити когнітивний, психолінгвістичний і лінгвопрагматичний аспекти, можна по-новому кваліфікувати роль метафори в аспекті мислення. Основний висновок сучасної науки без метафори немає творчого мислення. У прагматичному аспекті чітко простежується регулятивна функція терміна - інформаційна установка на конкретну дію [1, с. 27].

У мові й логіці спостерігається протиставлення понять «термін» «нетермін». Прагнення до чіткого розмежування терміна й інших мовних одиниць і до виділення особливих закритих систем, у яких функціонують терміни, позначилося й при визначенні співвідношення понять «термінологія» і «терміносистема». Під термінологією, як правило, розуміють «сукупність термінів, що обслуговують певну сферу знань, пов'язаних із системою понять: мистецтво, техніку, виробництво тощо. Це особливий пласт лексики, який піддається свідомому регулюванню та впорядкуванню [7, с. 683]. 
При розмежуванні понять «термінологія» і «терміносистема» В.М. Лейчик акцентує на тому, що сукупності термінів можуть утворюватися як стихійно, так і свідомо. Дослідник пропонує називати стихійно сформовану сукупність термінів термінологією, а сформовану свідомо - терміносистемою. При цьому базовою частиною терміносистеми $\epsilon$ сконструйована й реалізована в знаковій формі система понять, або логічна схема, у центрі якої перебуває ядро - основне поняття, і від нього розходяться інші поняття, що позначають види, ознаки, функції, процеси й суміжні об'єкти. Між різними видами понять існують родо-видові, функціональні, атрибутивні та інші види логічних зв'язків. Проте подібна логічна схема ще не є терміносистемою. Для створення повноцінної терміносистеми, на думку В.М. Лейчика, до логічної схеми необхідно додати дефініції понять, підібрати терміни, які адекватно виражають ці поняття, і впорядкувати терміносистему таким чином, щоб кожному терміну відповідало одне поняття [5, с. 192].

Аналізуючи функції, виконувані терміном, В.М. Лейчик виділяє номінативну, сигніфікативну, комунікативну, прагматичну й евристичну [5, с. 78-79]. Наприклад, у номінативній щодо економічної сфери подані одиниці позначають певні об'єкти діяльності людини (чек, сертифікат, банкнота та ін.); у сигніфікативній (функції позначення) - актуалізуються значення кожної з лексичних одиниць, які організовують економічну термінологію в цілому (діяча - торговець, споживач, виробник, продавеиь, гравець, економіст, стратег; дії - позичати; ознаки - позикові кошти, поточна політика, імпорт одягу, грочово-кредитна політика тощо). Комунікативна - функція передачі знання (навчання, спілкування фахівців тощо), яка сприяє спілкуванню зі спеціалістом у галузі економіки, що передбачає знання вузькопрофесійної лексики економічної підмови. Прагматична функція («експресивна») спрямована на вирішення певного кола завдань і досягнення будь-яких цілей; в евристичній функції термін виступає як інструмент пізнання.Природним місцем існування для терміна, за висновками науковців, виступає самостійний функціональний різновид загальнолітературної мови, традиційно названий мовою науки. Л.Ю. Буянова в роботі, присвяченій проблемам термінологічної деривації мови науки, подає таку його характеристику: «Концептуально-когнітивний простір мови науки структуровано й організовано; мовні механізми, що визначають адекватність функціонування всіх його рівнів, когерентні й імпліцитно детерміновані антропоцентричною природою мови в цілому. Відповідно, наукове пізнання світу (предметно-просторових i подійночасових аспектів у їхній динамічній мінливості), неможливе поза мовною особистістю, обумовлює гетерогенність спектра поглядів на 
досліджуваний об'єкт. Мова науки як специфічне знаряддя пізнання зумовлює створення як цілісної мовної картини світу і іiі текстури, так i субкартин (предметного, атрибутивного, квантитативного, каузального, локально-темпорального та ін. світів)» [2, с. 44]. Отже, специфіка терміна як оперативної одиниці мови науки відображає його найтісніший зв'язок 3 самою сферою мови науки, яким у межах цього дослідження виступає мова економічного блоку наук.

Для системи економічних понять, неоднорідних за своїм змістом i роллю, виконуваною ними, одночасно характерні єдність, цілісність та ієрархічна організація елементів. Неоднорідність змісту економічних понять прямо залежна від особливого місця економіки як системи. Специфіка економіки відбивається в економічній термінології, де, поряд 3 власне економічними термінами, функціонують терміни, залучені 3 інших терміносистем (правової, історичної, географічної та інших).

Економічна термінологія, на нашу думку, є продуктом історичного розвитку. У ній відображені послідовні етапи економічних змін у суспільстві, для кожного з яких характерна своя особлива лексика, що вказує на характер відповідних виробничих відносин. Соціальноекономічні зміни знаходять відображення у виникненні нових ключових слів, які характеризують певний історичний етап суспільного розвитку. Так, у для періоду перебудови для економічної ситуації були характерні такі терміни, як приватизачія, ваучер, дефолт, деномінаиія. Для нинішнього етапу це такі терміни, як депозит, маркетинг, інвестиція, мерчандайзер, збут, прибуток тощо. Ці слова, як правило, складають базисну термінологію і входять до неї як необхідний і обов'язковий елемент. 3 одного боку, вони використовуються носіями мови для позначення відповідних процесів і явищ, з іншого - $\epsilon$ засобами пізнання цих процесів і явищ, з поглибленням пізнання сутності яких виявляються нові особливості цих процесів і явищ, з чим пов'язане вироблення нового кола понять. Для їх позначення й розкриття створюються нові терміни або переосмислюються наявні.

При вивченні прагматики й семіотики економічної терміносистеми, безумовно, актуальним є підхід до терміна і як до одиниці дискурсу. Передумовою виокремлення економічного дискурсу є неодноразова згадка про стрімкий розвиток економічної термінології й перехід іiі до загальновживаної лексики. У той же час, як зазначає Г. Яроцька, сама структура економічного терміна, його зміст зазнають суттєвих змін через необхідність адекватно відображати економічну реальність а також нав'язувати певне іiі бачення, «використовуючи» процеси фокусування / дефокусування, тобто здійснюючи когнітивну обробку й наступну 
відповідну репрезентацію інформації [8, с. 78]. Кількісний аналіз фактичного матеріалу, відібраного з українського інтернет-виданнь наочно демонструє, що в дискурсивному просторі економічної сфери частотні терміноодиниці. Проаналізовані приклади ілюструють, що структура й семантика економічних термінів різноманітні, оскільки ці мовні одиниці створювалися для термінологічної номінації різноманітних фрагментів цілісного економічного простору, що й зумовило структурне та семантикосеміотичне розмаїття термінів. Це пояснюється тим фактом, що створений термін не тільки виконує номінативну функцію, тобто називає поняття, але й відображає у своїй формально-когнітивній структурі це поняття. Хоча позначення певного поняття саме цим словом або словосполученням явище значною мірою умовне, для фахівців будь-якої наукової сфери та галузі професійної діяльності небайдуже, яким терміном їм доводиться оперувати, і тому терміни оцінюються як вдалі, не зовсім вдалі й зовсім непридатні. Це свідчить про те, що велике значення для теорії терміна має поняття деривації. У процесі деривації відбувається зміна форми (структури) й семантики одиниць, взятих за вихідні в смисловому плані. Ця зміна може бути пов'язана або з використанням термінологічного знака в новому значенні, або зі створенням нового знака (терміна) шляхом перетворення старого або його комбінації з іншими знаками мови з тією ж метою.

Також необхідно враховувати, що терміни, як і інші знаки національної мови, не статичні, а постійно змінюються під час еволюції суспільства і його сфер діяльності - наукової, технічної, виробничої, економічної, політичної тощо. Усі найважливіші періоди створення, існування й функціонування термінів не випадкові, а формують певну структуру просторово-часових зв'язків, систему понятійно-категоріальних зв'язків, відносин, функцій, що спостерігається і в економічній терміносфері.

Можна констатувати, що економічна термінологія, у якій поряд із власне економічними функціонують також терміни, залучені з інших термінологічних систем (правової, географічної, історичної та ін.), $є$ продуктом історичного розвитку й відображає всі етапи економічних змін у суспільстві, кожен з яких характеризується своєю специфічною лексикою, яка описує відповідний рівень виробничих відносин. Система економічних понять, будучи відображенням економіки як системи, характеризується єдністю, цілісністю, ієрархічною організацією елементів, які неоднорідні за своїм змістом і виконуваними функціями. Економічна терміносистема, будучи системою знаковою, має як загальномовні особливості, так і ознаки, властиві тільки їй. Логічність, 
аргументованість викладеного змісту в економічних текстах $є$ важливим фактором, адже явища в галузі економіки вимагають підкреслено фактологічної точності висловлювання. Однак, незважаючи на підвищений інтерес до цієї проблем, серед лінгвістів і досі не існує єдиного розуміння процесу міграції термінологічної лексики, зокрема економічних одиниць, в загальновживаний мову, що потребує подальшого ретельного аналізу й окреслює перспективи наукових досліджень у цьому напрямі.

\section{Література:}

1. Архипенко Л.М. Особливості адаптації запозичень 3 німецької мови в системі української економічної термінології // Одеський лінгвістичний вісник. Науково-практичний журнал. Спецвипуск, 2017. C. $26-29$

2. Буянова Л.Ю. Терминологическая деривация в современном русском языке (метаязыковой аспект). Краснодар: КубГУ, 1996. 252 с.

3. Гумбольдт В. Избранные труды по языкознанию. М.: Прогресс, 1984. $400 \mathrm{c}$.

4. Даниленко В.П. Лексико-семантические и грамматические особенности слов-терминов // исследования по русской терминологии. М., 1971. C. 7-67.

5. Лейчик В.М. Терминоведение: предмет, методы, структура. 2-е изд. М. : КомКнига, 2006.

6. Термінологічний словник 3 питань запобігання та протидії легалізації (відмиванню) доходів, одержаних злочинним шляхом, фінансуванню тероризму, фінансуванню розповсюдження зброї масового знищення та корупції / Чубенко А.Г., Лошицький М.В., Павлов Д.М., Бичкова С.С., Юнін О.С. Київ : Ваіте, 2018. 826 с.

7. Українська мова : енциклопедія. Київ: Вид-во «Українська енциклопедія» ім. М. П. Бажана, 2004. 820 с.

8. Яроцкая Г.С. Основные лингвистические направления исследования экономического дискурса // Науковий вісник Міжнародного гуманітарного університету. Сер.: Філологія. 2014 №10. Том 2. С. 78-80. 